\title{
Functional and Economic Analysis of Plate-Screw and Percutaneous Pinning in Radius Distal End Fractures
}

\author{
Distal Radius Kırıklarında Plak-Vida ve Perkütan Çivilemenin Fonksiyonel ve Ekonomik Değerlendirilmesi
}

\author{
Hüseyin Așkar', Uğur Erdem Ișıkan², Ali Bilge³ ${ }^{3}$ Ali Levent², Mehmet Akif Altay² \\ ${ }^{I}$ Samandă̆ State Hospital, Department of Orthopaedics And Traumatology, Hatay; ${ }^{2}$ Department of Orthopaedics and Traumatology, Harran \\ University, Faculty of Medicine, Şanluurfa; ${ }^{3}$ Department of Orthopaedics and Traumatology, Kafkas University, Faculty of Medicine, Kars
}

\begin{abstract}
AIM: The primary objective in surgical treatment of radius distal end (RDE) fractures is to compose a functional wrist with no delay and to minimize labor-force loss. In this retrospective study the aim has been to draw a comparison between anatomic and functional results of RDE-fracture patients treated with $\mathrm{K}$-wires or plate-screw application and make a comparison amidst anatomic and functional results as well as overall cost.
\end{abstract}

METHODS: Fifty four radius distal end fracture diagnosed cases surgically treated between dates April 2004 and July 2009 have been analyzed retrospectively. Patients treated with plate-screw and osteosynthesis have been classified under Group 1, patients treated with percutaneous pinning have been classified under Group 2. The patients have been anatomically and functionally analyzed. Additionally, cost analyses have been evaluated for both groups.

RESULTS: With respect to anatomical and functional scoring, no statistically meaningful difference could be detected between both groups. Between anatomical scoring and functional scoring a very high level of statistically meaningful difference could be detected. This finding indicates that when a brilliant score is received in anatomical scoring, a corresponding achievement can be obtained in functional scoring too. In the comparison between hospitalization length and treatment costs, both predictors have been detected significantly high in Group 1.

CONCLUSION: No meaningful difference has been obtained between both groups with respect to anatomic and functional results; however it has been detected that percutaneous pinning is substantially effective in reducing length of hospitalization and treatment costs.

Key words: radius fractures; costs and cost analysis; bone screws

\section{ÖZET}

AMAÇ: Radius distal uç (RDU) kırıklarının cerrahi tedavisinde temel amaç en kısa sürede fonksiyonel bir el bileği eklemi elde etmek ve ișgücü kaybını en aza indirmektir. Geriye dönük olarak planlanan

Uzm. Dr. Hüseyin Aşkar, Hatay, Türkiye

Tel.05052998414 Email.askarbuseyin@mynet.com

Gelis Taribi: 14.04.2016 • Kabul Tarihi:02.09.2016 bu çalıșmada RDU kırı̆̆ı nedeniyle K-telleri ya da plak-vida uygulanarak tedavi edilen hastaların anatomik ve fonksiyonel sonuçları ile maliyetlerinin karșılaștırıması amaçlandı.

YÖNTEM: Nisan 2004 - Temmuz 2009 tarihleri arasında radius distal uç kırığı tanısı konularak cerrahi olarak tedavi edilen 54 olgu geriye dönük olarak değerlendirildi. Plak-vida ile osteosentez uygulanan hastalar Grup 1, perkütan çivileme uygulanan hastalar ise Grup 2 olarak değerlendirildi. Hastalar anatomik ve fonksiyonel olarak değerlendirildi. Ayrıca her iki grup için maliyet analizleri değerlendirildi.

BULGULAR: Anatomik ve fonksiyonel skorlama açısından her iki grup arasında istatistiksel olarak anlamlı bir fark bulunamadı. Anatomik skorlama ile fonksiyonel skorlama arasında çok iyi düzeyde istatiksel olarak anlamlı bir ilișki saptandı. Bu sonuç anatomik skorlamada çok iyi sonuç elde edildiği zaman fonksiyonel skorlamada da aynı büyüklükte bașarı gözleneceğini göstermektedir. Hastanede yatıș süresi ve tedavi maliyetlerinin karșılaștırılmasında ise Grup 1'de her ikisinin de anlamlı derecede yüksek olduğu tespit edildi.

SONUÇ: Her iki grup arasında anatomik ve fonksiyonel sonuçlar açısından anlamlı bir fark elde edilmemesine karșın perkütan çivilemenin ciddi olarak hastanede kalıș süresini ve tedavi maliyetini azalttığı gösterilmiștir.

Anahtar kelimeler: radius kırıkları; giderler ve maliyet analizi; kemik vidaları

\section{Introduction}

Distal radius fractures are among the most common injuries during clinical practices ${ }^{1}$. Therefore, although a wide variety of treatment modalities such as closed reduction and pinning, external fixators and open reduction and plate-screw application are defined in the treatment of distal radius fractures in the literature, it has not yet developed a full consensus ${ }^{2}$. Although the outcomes are usually connected to the diagnostic and treatment methods, long-lasting pain and limitations on the level that affect their daily life function in the wrist joints are not substantial number. These problems occur not only after complex fractures but also 
after simple injuries and cause a significant amount of resource consumption in respect to health care costs as well as creating serious health problems ${ }^{3}$. In clinical trials, functional outcomes have been reported to be better after stable fixators which providing anatomical joint alignment and allowing early mobilization ${ }^{4-6}$. However, in some studies, it has been reported that anatomic alignment is not always sufficient to achieve satisfactory clinical outcome, good functional outcomes are achieved in some patients who anatomic alignment can not be provided ${ }^{7,8}$. Poor outcomes are usually associated with radial shortening and volar tilt in periarticular fractures of the distal radius ${ }^{9,10}$.

Although internal fixation may seem like the best alternative among surgical treatment options ${ }^{11}$, multiple fragments, osteochondral lesions and ligament injuries reduce the chances of success of internal fixation in complex fractures ${ }^{12}$ The two treatment methods could not be shown in full superiority to each other in clinical trials in which internal and external treatment alternatives to be compared ${ }^{1,13}$

The main goal of surgical treatment of distal radius fractures is to achieve a functional wrist joint as soon as and minimize the loss of manpower. However, especially in recent years, together with health care costs beginning to keep an important place among economic costs of countries, the efficient use of the resources of the social security system as well as functional outcomes have also gained significant importance.

Percutaneous pinning is applied in the treatment of distal radius fractures after both plate-screw osteosynthesis and closed reduction. Our hypothesis in this study is that percutaneous pinning will reduce duration of surgery and hospitalization and also lower the cost per patient after closed reduction under fluoroscopy control under general anesthesia. With this purpose, outcomes of patients who undergo percutaneous pinning as surgical treatment after platescrew osteosynthesis or closed reduction due to distal radius fracture were evaluated anatomically and functionally as well as were compared by considering the cost analysis in our study.

\section{Patients and Method}

After obtaining permission from the local ethics committee, 54 cases with diagnosis of distal radius fracture were evaluated retrospectively to admitted to Harran University Research and Application
Hospital and EMOT (hand microsurgery orthopedics and traumatology) hospital between July 2004 and July 2009. While patients who had distal radius fracture were involved in the study, patients who had open fractures, segmental fractures, pathological fractures, poor general condition and exposed to multiple trauma were excluded from the study because they affect recovery potential. As a general treatment, all patients who admitted to the emergency room firstly were treated with closed reduction and long-arm cast. Then Group 1 was considered as patients undergoing osteosynthesis with a plate-screw, Group 2 was considered as patients undergoing percutaneous pinning among patients who had angulation more than 15 degrees, the intra-articular step-off above $2 \mathrm{~mm}$ and the radial shortening above $2 \mathrm{~mm}$ at any plan in control $\mathrm{X}$-rays. Demographic data and mean follow up time of the cases were given in Table 1, the fracture mechanisms were given in Table 2 .

\section{Surgical Procedures}

Patients who undergo a plate-screw (Group 1) were operated between $0-4$ days after the opinion of anesthesia. While volar plate steel was applied to some patients, volar locked titanium plate was applied to others. Tourniquet was applied to the patient on the table in the supine position. Plate-screw application was performed by entering with Henry incision which made via flexor carpi radialis on the volar aspect of the wrist. Exercises and follow-up programs were performed after a short arm splint for two weeks following surgery.

Patients who undergo percutaneous pinning (Group 2) were taken to the operating room the same day. First-generation cephalosporin $(1 \mathrm{~g})$ was administered intravenously 30 minutes before surgery for antibiotic prophylaxis. Reduction was achieved under fluoroscopy by applying traction longitudinally to forearm after regional or general anesthesia. Two K-wires were sent to fracture line. Fixation was achieved with three or four K-wire in patients considered to be unstable. Long arm splint was applied after reduction control. Patients were discharged on the second day. Pins and splint were terminated at fourth week. Exercise and follow-up programs were performed.

\section{Assessment}

AO classification was used in the assessment of patients according to the fracture type (Table 3), Stewart scoring method ${ }^{14}$ and Gardland-Werley clinical assessment 
Table 1. Demographic data and average follow-up time of the cases

\begin{tabular}{llccc}
\hline & & Group 1 & Group 2 & Total \\
\hline Gender & Male & $24(\%)$ & $13(\%)$ & $37(\%)$ \\
& Female & $3(\%)$ & $14(\%)$ & $17(\%)$ \\
Age Average & & $40.3 \pm 8.6$ & $47.2 \pm 9.1$ & $7.6 \pm 5.3$ \\
Follow Time (month) & & $9.1 \pm 4.7$ & $11(\%)$ & 9.5 \\
Side & Left & $12(\%)$ & $16(\%)$ & $23(\%)$ \\
& Right & $15(\%)$ & $31(\%)$ \\
\hline
\end{tabular}

Table 2. The distribution of fracture occurence mechanism by groups

\begin{tabular}{lccc}
\hline Mechanism of occurence & Group 1 & Group 2 & Total \\
\hline Indoor falls & $6(\%)$ & $14(\%)$ & $20(\%)$ \\
Out falls & $8(\%)$ & $7(\%)$ & $15(\%)$ \\
Traffic accident inside of vehicle & $5(\%)$ & $2(\%)$ & $7(\%)$ \\
Traffic accident outside of vehicle & $5(\%)$ & $2(\%)$ & $7(\%)$ \\
Falling from height & $3(\%)$ & $2(\%)$ & $5(\%)$ \\
Sports injuries & 0 & 0 & 0 \\
\hline
\end{tabular}

Table 3. Staging by classification of $A O$

\begin{tabular}{lccc}
\hline & Group 1 & Group 2 & Total \\
\hline A2 & $2(\%)$ & $10(\%)$ & $12(\%)$ \\
A3 & 0 & $4(\%)$ & $4(\%)$ \\
B1 & 0 & $1(\%)$ & $1(\%)$ \\
B2 & 0 & $1(\%)$ & $1(\%)$ \\
B3 & $7(\%)$ & $1(\%)$ & $8(\%)$ \\
C1 & $3(\%)$ & $1(\%)$ & $4(\%)$ \\
C2 & $7(\%)$ & $7(\%)$ & $14(\%)$ \\
C3 & $8(\%)$ & $2(\%)$ & $10(\%)$ \\
\hline
\end{tabular}

application was not made for these patients. Moreover, although carpal tunnel Syndrome was observed in a case and scar tenderness was observed in the early stage of a case in Group 1, the complaints were observed to fell without any additional processing in these patients during follow-up. A statistically significant difference was found between the two groups for anatomic and functional scoring $(\mathrm{p}=0.051$ and $\mathrm{p}=0.341)$. Kendall's tau-b analysis from nonparametric correlation analyzes was performed between anatomical scoring and functional scoring. A statistically significant relationship was found a very good level between anatomical scoring and functional scoring $(\tau=0.06 \mathrm{p}=0.03)$. This outcome shows that the same amount of success will be observed in functional scoring when very good outcomes were achieved in anatomical scoring.

The functional score success of the methods was assessed with Pearson chi-square statistic analysis by stratifying fractures as a-b and c-type according to the AO classification between Group 1 and 2. Accordingly, a statistically significant difference was not found between each the three treatment types $\left(\chi^{2}=1.291, \mathrm{p}=0.524\right)$.

The outcomes of treatment modalities were stated in Table 6 and 7 for anatomic and functional scoring. The outcomes of functional scoring analysis were reported in Table 8 according to the $\mathrm{AO}$ classification. For both groups, outcomes were reported in Table 9 according 
Tablo 4. Method of Stewart scoring

\begin{tabular}{|c|c|c|c|c|c|c|}
\hline \multicolumn{7}{|c|}{ 4.1. Method of anatomic scoring } \\
\hline Dorsal angulation & \multicolumn{2}{|c|}{ Loss of radial length (mm) } & Loss of radial inclination & \multicolumn{3}{|c|}{ Scoring } \\
\hline Neutral & $<3 \mathrm{~mm}$ & & $0-4$ & \multicolumn{3}{|c|}{0} \\
\hline $1-10$ & $3-6 \mathrm{~mm}$ & & $5-9$ & \multicolumn{3}{|c|}{1} \\
\hline $11-14$ & $7-11 \mathrm{~mm}$ & & $10-14$ & \multicolumn{3}{|c|}{2} \\
\hline$>14$ & $>11 \mathrm{~mm}$ & & $>14$ & \multicolumn{3}{|c|}{4} \\
\hline \multicolumn{7}{|c|}{ Excellent $=0$; Good=1-3; Fair $=4-6 ;$ Poor $=7-12$} \\
\hline \multicolumn{7}{|c|}{ 4.2. Method of functional scoring - subjective complaints } \\
\hline Pain & Limitation of movement & Disability & Restriction of activity & Results & & Scoring \\
\hline None & None & None & None & Excellent & & 0 \\
\hline Occasional & Slight & None & None & Good & & 2 \\
\hline Occasional & Slight & None if careful & Present & Fair & & 4 \\
\hline Often & Present & Present & Marked & Poor & & 6 \\
\hline \multicolumn{7}{|c|}{ 4.3. Objective evaluation } \\
\hline Movement/Function & & \multicolumn{2}{|c|}{ Angulation of Movement } & \multicolumn{3}{|c|}{ Scoring } \\
\hline Dorsiflexion & & \multicolumn{2}{|c|}{$<45$} & \multicolumn{3}{|c|}{5} \\
\hline Palmar flexion & & \multicolumn{2}{|c|}{$<30$} & \multicolumn{3}{|c|}{1} \\
\hline Ulnar deviation & & \multicolumn{2}{|c|}{$<25$} & \multicolumn{3}{|c|}{3} \\
\hline Radial deviation & & \multicolumn{2}{|c|}{$<15$} & \multicolumn{3}{|c|}{1} \\
\hline Supination & & \multicolumn{2}{|c|}{$<50$} & \multicolumn{3}{|c|}{2} \\
\hline Pronation & & \multicolumn{2}{|c|}{$<50$} & \multicolumn{3}{|c|}{2} \\
\hline Circumduction & & & & & & \\
\hline Finger flexion & & Not to d & crease & & & \\
\hline Grip strength & & Loss 0 & ength & & & \\
\hline Radial/median neuritis & & Mild-I & rate & & & \\
\hline
\end{tabular}

to Stewart scoring system, outcomes were reported in Table 10 according to Gartland and Werley functional scoring system. Both of them have been found to be significantly higher in group 1 in comparison the length of stay in hospital and costs of treatment $(\mathrm{p}>0.05)$ (Table 11).

\section{Discussion}

Distal radius fractures constitute $75 \%$ of the patients with forearm fractures admitted to the emergency department and $16 \%$ of the fractures treated in the emergency department ${ }^{16,17}$. Therefore, treatment approach is still important today. In the literature, when average age of the studies related to the distal radius fractures is evaluated, Mc Queen et al. ${ }^{18}$ have reported that the average age was 69 in their study, Beaula et al. ${ }^{19}$ have reported that the average age was 51.2 in their study. In our study, the average age was $44.2 \pm 8.8$ for both groups. We consider that the reason for that our average age to be lower than literature may be the result of exposure to more trauma in the farmers' working period as regional feature. So that the 30-59 age group has constituted the majority of our patients in the study group.

It has been reported in various studies that plate-screw application with the dorsal approach is an alternative treatment to allow early action in the wrist ${ }^{20,21}$. However, it has been reported in some studies that 
Table 5. Clinical evaluation criteria of Gardland-Werley

\begin{tabular}{|c|c|}
\hline \multicolumn{2}{|l|}{ Residual deformity } \\
\hline Prominent ulnar styloid & 1 \\
\hline Residual dorsal tilt & 2 \\
\hline Radial deviation of hand & $2-3$ \\
\hline \multicolumn{2}{|l|}{ Subjective evaluation } \\
\hline Excellent (no pain, no movement restrictions) & 0 \\
\hline Good (Sometimes the pain, mild limitation of motion) & 2 \\
\hline $\begin{array}{l}\text { Fair (Sometimes the pain, restriction moderate movement, } \\
\text { wrist weakness) }\end{array}$ & 4 \\
\hline Poor (Pain, severe limitation in movement) & 6 \\
\hline \multicolumn{2}{|l|}{ Objective evaluation } \\
\hline Loss of Dorsoflexion & 5 \\
\hline Loss of Ulnar deviation & 3 \\
\hline Loss of Supination & 2 \\
\hline Loss of Palmar flexion & 1 \\
\hline Loss of Radial deviation & 1 \\
\hline Loss circumduction & 1 \\
\hline Distal radioulnar joint pain & 1 \\
\hline \multicolumn{2}{|l|}{ Complications - arthritic changes } \\
\hline Minimal & 1 \\
\hline Minimal with pain & 3 \\
\hline Moderate & 2 \\
\hline Moderate with pain & 4 \\
\hline Severe & 3 \\
\hline Severe with pain & 5 \\
\hline Nerve complications (median) & $1-3$ \\
\hline Poor finger function due to cast & $1-2$ \\
\hline
\end{tabular}

this approach increases incidence of complications especially such as irritation of the tendons and tendon rupture $^{13,22}$. Therefore, volar approach has become more commonly used by coming up the agenda suitable locking plates for the use of angled screws ${ }^{2}$. Jupiter and Marent-Huber ${ }^{23}$ have reported that they achieved a significant increase in motion, grip strength, and patient satisfaction between six months and a year, $96 \%$ good and excellent outcomes according to GardlandWerley clinical evaluation criteria at the end of the two-year follow-up period in study in which they applied volar locking plate. In another clinical study, volar plate was applied in 93 cases in that it can not be successful with conservative method and it has been
Table 6. Evaluation of anatomic scoring of treatment

\begin{tabular}{cccc}
\hline & Excellent-Good & Fair-Poor & Total \\
\hline Group 1 & 27 & 0 & 27 \\
& $\% 100$ & $\% 0$ & $\% 100$ \\
Group 2 & 22 & 5 & 27 \\
& $\% 81.5$ & $\% 18.5$ & $\% 100$ \\
\hline
\end{tabular}

Table 7. Evaluation of functional scoring of treatment

\begin{tabular}{cccc}
\hline & Excellent-Good & Fair-Poor & Total \\
\hline Group 1 & 25 & 2 & 27 \\
& $\% 92.6$ & $\% 7.4$ & $\% 100$ \\
Group 2 & 24 & 3 & 27 \\
& $\% 88.9$ & $\% 11.1$ & $\% 100$ \\
\hline
\end{tabular}

Table 8. Functional scoring analysis according to the AO classification

\begin{tabular}{ccccc}
\hline & $\mathrm{A} 0$ & Excellent-Good & Fair-Poor & Total \\
\hline Group 1 & & & & \\
& $\mathrm{Ab}$ & $9(\% 100)$ & 0 & 9 \\
& $\mathrm{C}$ & $16(\% 88.9)$ & $2(\% 11.1)$ & 18 \\
Group 2 & & & & \\
& $\mathrm{Ab}$ & $15(\% 88.2)$ & $2(\% 11.8)$ & 17 \\
& $\mathrm{C}$ & $9(\% 90)$ & $1(\% 10)$ & 10 \\
\hline
\end{tabular}

Tablo 9. Evaluation with both groups of Stewart scoring system

\begin{tabular}{llccc}
\hline & & Group 1 & Group 2 & Total \\
\hline Functional & & & & \\
& Excellent & $14(\%)$ & $17(\%)$ & $31(\%)$ \\
& Good & $11(\%)$ & $7(\%)$ & $18(\%)$ \\
& Fair & $2(\%)$ & $3(\%)$ & $5(\%)$ \\
Anatomic & & & & \\
& Excellent & $22(\%)$ & $13(\%)$ & $35(\%)$ \\
& Good & $5(\%)$ & $9(\%)$ & $14(\%)$ \\
& Fair & 0 & $4(\%)$ & $4(\%)$ \\
& Poor & 0 & $1(\%)$ & $1(\%)$ \\
Objective & & & & \\
& Excellent & $20(\%)$ & $19(\%)$ & $39(\%)$ \\
& Good & $7(\%)$ & $8(\%)$ & $15(\%)$ \\
& Fair & 0 & 0 & 0 \\
\hline
\end{tabular}

Table 10. Functional scoring system of Gartland and Werley

\begin{tabular}{ccccc}
\hline Gartland & & Group 1 & Group 2 & Total \\
\hline & Excellent & $18(\% 66.7)$ & $19(\% 70.3)$ & $37(\%)$ \\
& Good & $8(\% 29.6)$ & $6(\% 22.2)$ & $14(\%)$ \\
& Fair & $1(\% 3.7)$ & $2(\% 7.5)$ & $3(\%)$ \\
Poor & 0 & 0 & 0 \\
\hline
\end{tabular}

Table 11. Length of staying of patients in hospital and cost of treatment for the groups

\begin{tabular}{|c|c|c|}
\hline & $\begin{array}{l}\text { Length of staying of } \\
\text { patients in hospital }\end{array}$ & $\begin{array}{c}\text { Cost of } \\
\text { treatment }\end{array}$ \\
\hline Group 1 & 4 days & $\begin{array}{c}1146 \text { TL+Implant } \\
\text { (Titanium: } 2500 \mathrm{TL}): 3646 \mathrm{TL} \\
\text { 1146 TL+Implant } \\
\text { (Steel: } 300 \mathrm{TL}): 1446 \mathrm{TL} \\
866 \mathrm{TL}\end{array}$ \\
\hline
\end{tabular}


reported that $98.9 \%$ excellent and good outcomes were achieved at the end of an average 15 months ${ }^{24}$. Moreover, in this study, a and b groups were compared with $\mathrm{C}$ group according to the $\mathrm{AO}$ classification, it has been claimed that a significant difference could not be found functionally, functional outcomes are depending to extraarticular alignmen anatomic restoration of the articular surface. We have observed that the anatomical and functional outcomes correlate very significantly with each other, when very good outcomes are achieved anatomically, the success in the same size can be achieved in the functional scoring system in this study in which we reported the outcomes of average 9.5 month follow-up.

Lozano-Calderón et al. ${ }^{25}$ have reported that a statistically significant difference was not observed in clinical and radiological parameters between the two groups according to the Gartland-Werley system in a retrospective study in which they compared to volar plate with percutaneous pinning in a total 40 cases (17 pinning, 23 plates) consisting of group c by $70 \%$. Similarly, we did not observe a significant difference in functional between percutaneous pinning and volar plate fixation. Some authors claim that these fractures prone to collapse when pins are removed after percutaneous fixation ${ }^{26}$. Kurup et al. ${ }^{27}$ have concluded in their study that fractures do not undergo a significant loss reduction after pins are removed and this is not associated with AO classification, wire fixation period. Fixation with $\mathrm{K}$-wire is useful in respect to using together with other fixation methods in both intra-articular and extra-articular unstable fractures. In our study, there were no any collapse in fracture zone after pins are removed.

Problems such as tendon irritation, screw loosening could be observed in cases in that volar plate is applied, complications such as pin tract infection, loosening of the pins or the superficial radial nerve injury could be seen in cases in that percutaneous pinning is applied ${ }^{25}$. Pins are almost always placed in the radial styloid during percutaneous pinning applying to the distal radius fractures. There is a risk of injury to the superficial radial nerve during this application. In the cadaveric study made related to this, pins placed in Lister's tubercle were compared with pins placed in the styloid and pins applied the Lister's tubercle were observed to develop less nerve damage ${ }^{28}$. In our cases, although pins were applied from both Lister tubercle and the radial styloid, superficial radial nerve damage was not observed in any of our cases. Scar trace sensitivity is a problem that may be encountered after volar plate application. Some authors have argued that scar trace formed by volar incision is often more annoying than wire and pins applied externally ${ }^{25}$. In our study, although scar sensitivity was observed in the early stage in only a case in Group 1, the complaints were observed to decrease without any additional treatment during follow-up in our case.

The incidence of complications varies between 6-80\% in distal radius fractures ${ }^{29}$. In our study, the complication rate was $14.8 \%$ in total. The most common complication was distal radio-ulnar joint separation with six cases. All patients recovered without any problems. Moreover, reflex sympathetic dystrophy is a commonly complication especially in the long immobilized patients in this type of fractures. This rate was reported around $3.5 \%$ in the literature ${ }^{30}$. We consider that no any reflex sympathetic dystrophy in our study was depending on our average age being low, our cast time being short, our patients showing enough compliance for our physiotherapy advice.

Synn et al. ${ }^{31}$ stated that Gartland and Werley scoring system is not a good scoring system, we used this in order to compare with other studies. Although increasing the number of fracture fragments increases the rate for the exposure to the surgical intervention, there was no difference between the number of parts and functional outcome. Similarly, in our study, we have used Stewart's scoring system which we believe is more appropriate; but we also evaluated with Gartland and Werley scoring system in order to compare with other studies.

We consider that the main purpose of the surgical treatment of distal radius fractures should provide a highly functional recovery rather than correct the radiographic appearance. When our country's economic and socio-cultural conditions are considered, the cost of treatment with the functional outcomes should be not be neglected. In our study, it draws attention that percutaneous pinning is a cheaper surgical treatment method than plate-screw application. The cost of treatment is 3646 TL with volar locked titanium plate application, if steel plate is used instead of the titanium the cost of treatment is $1446 \mathrm{TL}$. However, the cost of treatment falls to $866 \mathrm{TL}$ in percutaneous pinning. Consequently, percutaneous pinning is cheaper $76 \%$ than titanium plates, $40 \%$ than steel plate.

In our study, when it is considered that there is no difference between functional outcomes, we consider that 
treatment options in distal radius fractures should be evaluated sensitively for economic aspect. However, although a relationship was not found between anatomical and functional outcomes in distal radius fractures, anatomic reduction can supply important especially in some occupational groups the young, active individuals, musicians and painters. Therefore, anatomical restoration should not be ignored to be the best in platescrew application. Plate-screw osteosynthesis may be preferred as a priority option, in such cases the subtle movements of the wrist joint are required.

In conclusion, although a significant difference was achieved in both groups for anatomical and functional outcomes in this study in which we compared to plate-screw application with percutaneous pinning after closed reduction, percutaneous pinning has been shown to seriously reduce the length of hospital stay and cost of treatment. By considering that surgical risks can be reduced in cases that can not be reducted by closed reduction, percutaneous pinning should be the first option after reduction under anesthesia. Volar locking plate application that provides excellent anatomic restoration may be preferred as a priority option in occupational groups in that the functional status of the hand is more important.

\section{References}

1. Cherubino P, Bini A, Marcolli D. Management of distal radius fractures: treatment protocol and functional results. Injury 2010;41(11):1120-6.

2. Egol K, Walsh M, Tejwani N, McLaurin T, Wynn C, Paksima N. Bridging external fixation and supplementary Kirschner-wire fixation versus volar locked plating for unstable fractures of the distal radius: a randomised, prospective trial. J Bone Joint Surg Br 2008;90(9):1214-21.

3. Villar RN, Marsh D, Rushton N, Greatorex RA. Three years after Colles' fracture. A prospective review. J Bone Joint Surg Br 1987;69(4):635-8.

4. Adani R, Tarallo L, Amorico MG, Tata C, Atzei A. The treatment of distal radius articular fractures through lcp system. Hand Surg 2008;13(2):61-72.

5. Jakob M, Rikli DA, Regazzoni P. Fractures of the distal radius treated by internal fixation and early function. A prospective study of 73 consecutive patients. J Bone Joint Surg $\mathrm{Br}$ 2000;82(3):340-4.

6. Kurup HV, Mandalia VM, Shaju KA, Singh B, Beaumont AR. Late collapse of distal radius fractures after K-wire removal: is it significant? J Orthop Traumatol 2008;9(2):69-72.
7. Arora R, Gabl M, Gschwentner M, Deml C, Krappinger D, Lutz M. A comparative study of clinical and radiologic outcomes of unstable colles type distal radius fractures in patients older than 70 years: nonoperative treatment versus volar locking plating. J Orthop Trauma 2009;23(4):237-42.

8. Batra S, Gupta A. The effect of fracture-related factors on the functional outcome at 1 year in distal radius fractures. Injury 2002;33(6):499-502.

9. Cooney WP. Distal radius fractures: external fixation proves best. J Hand Surg Am 1998;23(6):1119-21.

10. Keating JF, Court-Brown CM, McQueen MM. Internal fixation of volar-displaced distal radial fractures. J Bone Joint Surg $\mathrm{Br}$ 1994;76(3):401-5.

11. Leung F, Tu YK, Chew WY, Chow SP. Comparison of external and percutaneous pin fixation with plate fixation for intraarticular distal radial fractures. A randomized study. J Bone Joint Surg Am 2008;90(1):16-22.

12. Fernandez DL. Should anatomic reduction be pursued in distal radial fractures? J Hand Surg Br 2000;25(6):523-7.

13. Kreder HJ, Hanel DP, Agel J, McKee M, Schemitsch EH, Trumble TE, Stephen D. Indirect reduction and percutaneous fixation versus open reduction and internal fixation for displaced intra-articular fractures of the distal radius: a randomised, controlled trial. J Bone Joint Surg Br 2005;87(6):829-36.

14. Stewart HD, Innes AR, Burke FD. The hand complications of Colles' fractures. J Hand Surg Br 1985;10(1):103-6.

15. Gartland JJ Jr, Werley CW. Evaluation of healed Colles' fractures. J Bone Joint Surg Am 1951;33(4):895-907.

16. Handoll HH, Madhok R. Surgical interventions for treating distal radial fractures in adults. Cochrane Database Syst Rev 2003;(3): CD003209.

17. Handoll HH, Parker MJ. Conservative versus operative treatment for hip fractures in adults. Cochrane Database Syst Rev 2008; (3): CD000337.

18. McQueen M, Caspers J. Colles fracture: does the anatomical result affect the final function? J Bone Joint Surg $\mathrm{Br}$ 1988;70(4):649-51.

19. Beaulé PE, Dervin GF, Giachino AA, Rody K, Grabowski J, Fazekas A. Self-reported disability following distal radius fractures: the influence of hand dominance. J Hand Surg Am 2000;25(3):476-82.

20. Carter PR, Frederick HA, Laseter GF. Open reduction and internal fixation of unstable distal radius fractures with a lowprofile plate: a multicenter study of 73 fractures. J Hand Surg Am 1998;23(2):300-7.

21. Laseter GF, Carter PR. Management of distal radius fractures. J Hand Ther 1996;9(2):114-28.

22. Orbay J. Volar plate fixation of distal radius fractures. Hand Clin 2005;21(3):347-54.

23. Jupiter JB, Marent-Huber M; LCP Study Group. Operative management of distal radial fractures with 2 4-millimeter locking plates. A multicenter prospective case series. J Bone Joint Surg Am 2009;91(1):55-65. 
24. Gruber G, Bernhardt GA, Köhler G, Gruber K. Surgical treatment of distal radius fractures with an angle fixed bar palmar plating system: a single center study of 102 patients over a 2-year period. Arch Orthop Trauma Surg 2006;126(10):680-5.

25. Lozano-Calderón SA, Doornberg JN, Ring D. Retrospective comparison of percutaneous fixation and volar internal fixation of distal radius fractures. Hand 2008;3(2):102-10.

26. Brady O, Rice J, Nicholson P, Kelly E, O'Rourke SK. The unstable distal radial fracture one year post Kapandji intrafocal pinning. Injury 1999;30(4):251-5.

27. Kurup HV, Mandalia VM, Shaju KA, Singh B, Beaumont AR. Late collapse of distal radius fractures after K-wire removal: is it significant? J Orthop Traumatol 2008;9(2):69-72.
28. Glanvill R, Boon JM, Birkholtz F, Meiring JH, van Schoor AN, Greyling L. Superficial radial nerve injury during standard $\mathrm{K}$-wire fixation of uncomplicated distal radial fractures. Orthopedics 2006;29(7):639-41.

29. McKay SD, MacDermid JC, Roth JH, Richards RS. Assessment of complications of distal radius fractures and development of a complication checklist. J Hand Surg Am 2001;26(5):916-22.

30. Glowacki KA, Weiss AP, Akelman E. Distal radius fractures: concepts and complications. Orthopedics 1996;19(7):601-8.

31. Synn AJ, Makhni EC, Makhni MC, Rozental TD, Day CS. Distal radius fractures in older patients: is anatomic reduction necessary? Clin Orthop Relat Res 2009;467(6):1612-20. 